\title{
INCLUSION IN THE PRE-UNIVERSITY EDUCATION SYSTEM OF THE REPUBLIC OF KOSOVO, A GUARANTEED RIGHT WITHIN HUMAN RIGHTS AND FREEDOMS
}

\author{
MALIQE MULOLLI- JAHMURATAJ \\ PhD Candidate, Governance and Public Administration Branch, South East European University (SEEU) \\ Republic of Northern Macedonia, maliqem@gmail.com
}

\begin{abstract}
The education system is built on the concept of being in the service of all citizens of the country without distinction. In Kosovo the right to education is defined as category of law and the constitution. As this right is of a great interest and importance it reaches even further, it is also a category of human rights and freedoms envisaged in international mechanisms but directly applicable in Kosovo as a universal value.

This paper will address the concept of inclusiveness in the pre-university education system of the Republic of Kosovo as a right viewed within the scope of human rights and freedoms as a universal value of the democratic world. In addition, it will be addressed from the practical aspect of inclusiveness in Kosovo as an unalienable right.

In the view of what this paper is going to reflect to is that it will clearly identify how much inclusiveness is implemented and observed in the pre-university education of the Republic of Kosovo as a category of human rights and freedoms. First of all, it will have a reflection from a close view where does the Republic of Kosovo stand on observation of human rights and freedoms in terms of inclusion in the pre-university education system.
\end{abstract}

Keywords: inclusion, education system, human rights, legislation, fair policies.

\section{Introduction}

\section{The right to Education, a fundamental human right in the Republic of Kosovo}

Some human rights that men and women enjoy during their lives are not gifts that one person gives to another, the latter are rights acquired by birth. The rights acquired by birth are rights and their enjoyment are guaranteed irrespective of the will of a person or the state. The rights acquired by birth include the right to life, personal freedom, privacy, protection and that of education. The right to education is a right vested to every human being and it is one of the most fundamental and important rights for human life and development and place where he lives and works. Although it is a right acquired by birth, in order to have this right protected and preserved it stipulated starting with the international mechanisms that refer to the protection of human rights and freedoms, then in the Constitution as the highest legal act and followed by all relevant legislation. The right to education is everyone's right without discrimination, so inclusion is a right that enables every person to be part of the education system in order to develop themselves and place where they live and work.

The Republic of Kosovo considers the right to education to be a fundamental human right, a right for every citizen without any distinction. Since it is a right it is defined in the Constitution of the Republic of Kosovo, followed by in all relevant policies and legislation in force that refers to the right on education. In addition to regulating and defining the right to education, this right as a fundamental human right enables inclusion in the education system without discrimination the country must ensure.

Inclusion in the education system is part of the concept and clear orientation in the society and the Republic of Kosovo, due to the fact that the society and the Republic of Kosovo is oriented towards the universal values of human rights and freedoms claiming to be democratic country with rule of law. When referring this concept, we base it on the following facts: In its Constitution Kosovo has directly incorporated international mechanisms for 
the protection human rights and freedoms, and as such a model we are the only country in the world where the Constitution of the Republic of Kosovo has enshrined and defined relevant mechanisms for the protection of human rights, protection from discrimination, equal opportunities, protection of communities, etc.

In this paper we are going to address the right to education as a fundamental human right, and followed with what is to be highly important: the inclusion in the education system, which clearly means that in the Republic of Kosovo of the whole people enjoy right in the education system without a single distinction. All of them will be addressed as rights enshrined in international mechanisms as well as the Constitution and Laws. It is noteworthy to mention that the inclusion in the education system of the Republic of Kosovo is very well regulated, and it is defined to be implemented as mandatory in terms of human rights, however in practice some issues have emerged since we have failed in full implementation in terms of inclusion in the education system as a fundamental human right.

When referring to inclusiveness as a fundamental human right and particularly for the non- majority communities of Roma, Ashkali and Egyptian Communities in the Republic of Kosovo, these rights are protected and promoted for equal opportunities, this is clearly stipulated: "All persons belonging to the communities shall have the right to receive public education at all levels, in one of the official languages of Kosovo of their choice. Persons belonging to communities are entitled to pre-school, primary and secondary public education in their own language even if it is not an official language. The government sets reasonable and applicable thresholds for the establishment of special classes or schools operating in the languages of the communities. The minimum threshold for such classes or schools is lower than the thresholds normally set for institutions and school classes. Maximum thresholds will correspond to thresholds normally set for school classrooms. This is regulated by law." ${ }^{1}$. In reference to this we have a high level of legal certainty and respect for human rights, which guarantees the communities education in their language as fundamental right to their development and emancipation.

In 2001, the Assembly of Kosovo, based on the Constitutional Framework Of the Interim Self-Governance in Kosovo, adopted the Law on Preschool Education, where among other things, this Law , I quote: "Inclusiveness (see Convention on the Rights of the Child, Article 2) ${ }^{2}$ the member countries undertake to observe the rights referred to in this Convention and to guarantee them to all children, who subject to their jurisdiction, without discrimination of any kind, regardless of race, color, sex, language, religion, political opinion or any other opinion, of national, ethnic or social origin, property, disability, family background or any other condition of the child or his parents or his legal representatives " 3

Regarding the education of children with special needs, it is being implemented within the framework of the inclusive education system. This is a new philosophy that requires considerable effort to support individuals for full participation, unlike providing separate services for people with injuries. Children with special needs are children like all other children and therefore need to be educated together with other children in the same schools and classrooms, with all the support they need. The question arises: How much of this is actually taking place? We can say that not satisfactorily. If we rely on the data of recent years, the number of students with special needs involved in education has increased by $30 \%$. Out of 909 students in the school year 2008-2009, this number has increased to 1179 students, but again a large number of them still remain outside the educational institutions.

\section{Inclusion in the Education System, as a human right in the Republic of Kosovo}

The Republic of Kosovo is a country of all its citizens, without a discrimination, each of its citizens are equal and there is no discrimination regarding any rights. This is defined: "The Republic of Kosovo is a country of its own subjects. The Republic of Kosovo exercises its authority based on respect for the rights and freedoms of its citizens and all individuals within its borders." ${ }^{4}$ What the Constitution stipulates is legal certainty that the equality of citizens in the Republic of Kosovo is a constitutional category, despite the differences that citizens may have, the state will exercise equality and equal approach based on human rights and freedoms as universal values, observing certain rights that belong to certain communities. This acknowledges the approach of the Republic of Kosovo to observing of human rights and respect for its citizens without discrimination and this ensures equality, protection from discrimination and respect for human rights as the highest values of the democratic world. In terms of respect

\footnotetext{
${ }^{1}$ Law no. 03 / 1-047 on the Protection and Promotion of the Rights of Communities and their Members in the Republic of Kosovo, Article 8, paragraph 1;

${ }^{2}$ Convention on the Rights of the Child, Approved by the General Assembly of the United Nations, November 1989

${ }^{3}$ Law no. 02 / 1-52 on Preschool Education, Article 1

${ }^{4}$ Constitution of the Republic of Kosovo, Article 47, paragraph 2
} 
for human rights and freedoms, these apply not only to the protection of citizens by the state, but also to the sharing of goods and the stipulation of other rights that are important for their well-being and development within communities they belong to.

The right to and inclusion in the educational system of the Republic of Kosovo is one of the fundamental human rights, as a right stipulated as: "Every person enjoys the right to basic education free of charge. Compulsory education is regulated by law and funded by public funds. Public institutions provide every person with equal opportunities to be educated according to their particular abilities and needs." 5 Taking into consideration the stipulation in Constitution, it can be qualified as a legal certainty provided for every person regarding the right to education as a fundamental right for the development and usefulness of each person for himself, family and society.

In addition to the right to education, the Constitution ensures the equal opportunity to education, whereby it establishes equality for every citizen to education. In this context, the inclusion in the education system is it is precisely defined in the Constitution of the Republic of Kosovo referring it as: "according to his / her special abilities and needs". This provides that the within the right to education the Republic of Kosovo has defined and regulated inclusion as a value attributed to the progressive and developmental orientation of the Republic of Kosovo towards those who are qualified as universal values of the democratic world.

In the Republic of Kosovo, the authority and responsibility for drafting policies in the field of education is vested with the Ministry of Education, Science and Technology, among other things, the authority to: "To promote a non-discriminatory education system in which the right of every person to education is respected and the opportunities for quality education to be made available to all" ${ }^{6}$. With this, we have operationalization of what is defined in the highest legal act, the Constitution, specified further in the relevant legislation. Alongside the authority on drafting policies and legislation in the field of education, within its scope, a comprehensive approach to the education system as a human right is addressed and incorporated into any policy.

At no time the right to education is not denied, as the Ministry of Education has a duty to "promote a nondiscriminatory system of education in which the rights of every person for education and training are respected, and equal opportunities are provided to quality education; promote the protection of vulnerable groups within the education and vocational system; to ensure the health, safety and well-being of students and employees in the educational and vocational institution, as well as to promote measures to prevent dropout;" In line with what is defined in the relevant legislation on the pre-university education system, we acknowledge that the approach and orientation of the Republic of Kosovo is towards ensuring and promoting inclusion in the education system.

The Higher Education in the Republic of Kosovo education is regulated and requirements are defined. The right to higher education is defined and regulated as a right that enjoyed by every citizen of the Republic of Kosovo. For every of its citizens the Republic of Kosovo provides "equal opportunities and without discrimination to all students and staff in higher education institutions. " 7 . In addition to assuring education at the pre-primary level, this assurance is also for higher education, where within it is inclusiveness and not discrimination as values that are protected.

In addition to the legislation that addresses and regulates the right to education and inclusion as a concept of education development in the Republic of Kosovo, the Ministry of Education, Science and Technology has addressed and defined inclusion in its strategic documents. "Inclusive education provides a learning environment that provides access, accommodation and support for all students. This means that schools must be adapted for all children, irrespective of their physical, intellectual, social, emotional, linguistic or other factors. Inclusion aims to minimize inequalities in society, combat discrimination, avoid marginalization and exclusion, and ensure the wellbeing of all members of society. Therefore, it is necessary to implement educational policies and practices aimed at comprehensive processes, in particular in relation to marginalized social groups, such as people with special educational needs, non-majority communities, the poor, and some other social categories. $" 8$.

\footnotetext{
${ }^{5}$ Constitution of the Republic of Kosovo, Article 47, paragraph 1 and 2

${ }^{6}$ Law no. 03 / L-068 on Pre-University Education in the Republic of Kosovo, Article 3, paragraph 3;

${ }^{7}$ Law no. 04 / L-037 on Pre-University Education in the Republic of Kosovo, Article 2, paragraph 1.3;

${ }^{8}$ Ministry of Education, Science and Technology Kosovo, Strategic Education Plan in Kosovo 2017-2021, p. 42.
} 
The concept of inclusion in the education system is envisaged and regulated in the strategic plan of education in the Republic of Kosovo, a document which clearly defines the form and manner of concrete activities to implement inclusion in education as a right of every citizen of the Republic. Kosovo. The challenge in terms of inclusion in the education system and in order to be qualified as successful, among other things, are: the low level of involvement in the preschool education of children from non-majority communities of Roma, Ashkali and Egyptian as well as those of children with special needs, the involvement and low participation of children in education by marginalized groups, dropping out of school and non-enrollment in education, the poor economic and social situation of families. These are some of the challenges that accompany the entire involvement in the education system of the Republic of Kosovo.

The Kosovo Curriculum Framework, which includes the inclusiveness as one of its key principle upon which the New Kosovo Curriculum Framework was drafted. The whole Framework is designed by prioritizing inclusion and aiming to provide equal access for all without any discrimination based on gender, racial, religious, disability, economic status, etc. The Curriculum Framework of Pre-University Education of the Republic of Kosovo stipulates that "Irrespective of the format and purpose (ex. educational software, experimental or other package), teaching resources should be designed in accordance with the basic principles of the NQF enabling, among other things, the promotion of positive values, principles and experiences, such as: human rights, social justice and inclusion and the avoidance of prejudice and stereotypes, discriminatory attitudes, hatred and violence; " 9 . The curriculum is the core of the orientation in the pre-university education system and at the same time we have a clear definition of the principles regarding the inclusion in the education system as in human rights. Therefore, also in this document we have defined inclusion as a human right which must be implemented.

The Strategic Plan 2010 - 2015 on the organization of inclusive education of children with special educational needs in pre-university education in Kosovo, is a five-year plan which connects lifelong learning with involvement in education and provides equal opportunities for all. Education of children with special needs in this plan refers to the Strategic Plan 2010-2015 on the inclusion of children with special needs, a document drafted in 2010. What this document defines is very clear and very substantial, where: "Establishing an inclusive educational community is the duty of every member of society, thus the responsibility to give our utmost contribution to the realization of activities envisaged falls with each of us, having full confidence that it is the society that benefits the most from it. " 10

Strategic Plan 2010-2015 on the inclusion of children with special needs in pre-university education, is a strategic plan which the Ministry of Education, Science and Technology refers to for children with special needs. The plan in question is structured in such a way that it clearly explains how to approach and how to address inclusion issues as functionally as possible.

Individual Education Plan-IEP (pedagogical document), is an official document for children with special needs drafted by a group of experts in the relevant fields that enables to follow the attainment and progress of a child. This plan is being implemented in almost all schools where there are children with special needs and day by day its application is improving. ${ }^{11}$ This acknowledges that the Ministry of Education, Science and Technology has taken seriously the issue of inclusion with special emphasis on children with special needs and we do not forget to mention that this is another requirement that Kosovo must be met in order to get integrated into the European Union.

"We know that the world is an inclusive community. It is very important for children to have the opportunity to learn and grow within the communities that represent the world they will live after they finish high school." 12

Notwithstanding the fact that the inclusiveness stems out form the Constitution of the Republic of Kosovo, relevant legislation and other strategic documentation, it is ensured as a right of every citizen of the Republic of Kosovo which constitutes the observation of human rights, in the field and in practice the situation is not good and it has done with inadequate implementation of relevant legislation and documents. It is very positive that the inclusiveness constitutes a right, but commitment should be in the implementation of this human right by including

\footnotetext{
${ }^{9}$ Curriculum Framework for Pre-University Education of the Republic of Kosovo, Pristina, August 2011, p. 59

${ }^{10}$ Strategic Plan on the Organization of Inclusive Education of Children with Special Educational Needs in Pre-University

Education in Kosovo 2010 - 2015, p. 3

${ }^{11}$ http://masht.rks-gov.net/uploads/2015/06/dokumnetet-e-masht-it-sigurojne-arsimin-eneral-p-p-rfshir-sn- kosov-3.pdf

${ }_{12}$ Mara Sapon-Shevin
} 
every citizen of the Republic of Kosovo it the education system and this by combining the will of the relevant institutions and the highest demands of every citizen of the Republic of Kosovo without any kid of discrimination.

\section{Conclusion and Recommendations}

By addressing this material and incorporating it in this paper in this paper, I have come to the conclusion that the Republic of Kosovo is among the countries that have provided to a highest level of legal acts the right to education, i.e., inclusion as a human right. It is to be highly appreciated the political and decision-making will in the Republic of Kosovo, that it qualified the inclusion as a Constitutional right followed in the relevant legislation of the country. In addition, inclusion is one of the basic principles that the relevant institutions in Kosovo in charge for Education are led by when drafting of policies and strategic documents for the development of education in the Republic of Kosovo.

Relevant institutional mechanisms of the Republic of Kosovo qualify and include inclusiveness from the point of view of human rights, due to the fact that inclusion in the relevant documentation on education system represents a basic principle, namely observation of human rights and freedoms in terms of inclusion in education.

It is common that during the preparation of the paper and addressing of the material to encounter issues which will need reflection in order to have a more developed and present inclusion in the educational system of the Republic of Kosovo. Therefore, in the following I will present the suggestions which would be a reference point for institutions and other mechanisms to fully reflect the change, implementation or other activities in order to strengthen inclusion in the education system of the Republic of Kosovo as a fundamental human right, as in the following:

Relevant institutional mechanisms should establish appropriate mechanisms for assessing the implementation of relevant legal provisions regarding the inclusion in the education system of the Republic of Kosovo.

Having an assessment on the implementation of policies and legislation regarding inclusion, we should have a complementary change in policies and legislation that would be in the function of inclusion in education as a human right. Being that it constitutes human right it should be the basic principle on which is build every policy, legislation and strategic document planning to change the educational system of the Republic of Kosovo.

In whatever form we refer to inclusiveness, we must keep in mind that this is a human right and for this the Republic of Kosovo will be evaluated in terms of how it is being implemented, acknowledging that its implementation is of great importance for a country with rule of law.

In addition to the development of relevant inclusion mechanisms, there must be development in the socioeconomic aspect, for the mere fact that inclusion is related to the socio-economic status of the families of the category that inclusion is ensured as a fundamental human right.

Awareness campaigns for inclusion in the education system will need to be active on a regular basis, given that such a right need reminding and demonstration to show benefits of inclusion in the education system as an entitled right. 
ISSN 2661-2666 (Online) International Scientific Journal Monte (ISJM) DOI: 10.33807/monte.202004665 No. 2 (2020): April

\section{References}

Constitution of the Republic of Kosovo. Law no. 03 / L-068 on Pre-University Education in the Republic of Kosovo, Article 3, paragraph 3;

Constitution of the Republic of Kosovo. Law no. 03 / 1-047 on the Protection and Promotion of the Rights of Communities and their Members in the Republic of Kosovo;

Constitution of the Republic of Kosovo. Law no. 04/1 -037 on Pre-University Education in the Republic of Kosovo, Article 6, paragraph 2;

Constitution of the Republic of Kosovo. Law no. 02 / 1-52 on Preschool Education, Article 1

Kosovo Strategic Education Plan 2017-2021. Retrieved from: https://masht.rksgov.net/uploads/2017/02/20161006-kesp-2017-2021-1.pdf

Curriculum Framework for Pre-University Education of the Republic of Kosovo, Pristina, August 2011, p. 59

Strategic plan for the organization of inclusive education of children with special educational needs in preuniversity education in Kosovo 2010 - 2015; p. 3 http://masht.rks-

gov.net/uploads/2015/06/dokumnetet-e-masht-it-sigurojne-arsimin-eneral-p-p-rfshir-sn-kosov-3.pdf 